\title{
Hubungan Protein Urine dengan Laju Filtrasi Glomerulus pada Penderita Penyakit Ginjal Kronik Dewasa di RSUP Dr. M.Djamil Padang tahun 2015-2017
}

\author{
Arief Meiji Surya ${ }^{1}$, Dian pertiwi ${ }^{2}$, Masrul $^{3}$
}

\begin{abstract}
Abstrak
Penyakit ginjal kronik adalah kelainan struktur dan penurunan faal ginjal yang telah berlangsung lebih dari tiga bulan. Gangguan fungsi ginjal dapat ditentukan berdasarkan nilai laju filtrasi glomerulus, tetapi dengan metode sederhana bisa juga melalui pemeriksaan protein urine. Tujuan penelitian ini adalah menentukan hubungan protein urine dan laju filtrasi glomerulus pada penderita penyakit ginjal kronik dewasa di RSUP Dr. M. Djamil Padang dari 2015 sampai 2017. Penelitian ini merupakan studi analitik dengan pendekatan cross sectional. Pengambilan sampel dilakukan secara purposive random sampling dengan jumlah sampel sebanyak 40 data rekam medis penderita penyakit ginjal kronik dewasa yang telah memeriksakan protein urine dan laju filtrasi glomerulus melalui hasil pemeriksaan kreatinin serum. Data dianalisis menggunakan analisis statistik univariat dan bivariat menggunakan uji Kruskal-Wallis. Hasil analisis univariat didapatkan karakteristik dari sampel penderita penyakit ginjal kronik yang terbanyak adalah jenis kelamin laki-laki dan berumur lebih dari 60 tahun. Penyebab terbanyak adalah nefropati diabetes. Rerata laju filtrasi glomerulus sampel adalah $9,178 \mathrm{~mL} / \mathrm{mnt}$ per $1,73 \mathrm{~m}^{2}$. Pemeriksaan protein urine sampel didapatkan hasil yang terbanyak adalah +3 . Hasil analisis bivariat didapatkan $p=0,118$. Simpulan studi ini adalah tidak terdapat hubungan yang bermakna antara protein urine dan laju filtrasi glomerulus pada penderita penyakit ginjal kronik dewasa di RSUP Dr.M.Djamil Padang dari 2015 sampai 2017.
\end{abstract}

Kata kunci: penyakit ginjal kronik, protein urine, laju filtrasi glomerulus

\begin{abstract}
Chronic Kidney Disease (CKD) is structural and functional disruption of kidney for more than three months. Kidney function disruption is determined by glomerular filtration rate (GFR) or simply by urine protein test. The objective of this study was to determine the relationship between urine protein and GFR of patients having chronic kidney disease in Dr. M. Djamil Padang General Hospital since 2015 until 2017. The study was analytical using crosssectional design. The samples were chosen by purposive random sampling technique to get 40 adult patients who have chronic kidney disease with by urine protein test and serum creatinine examination. Data were analyzed by univariate statistic and bivariate data using Kruskal-Wallis test. Univariate anaylisis found that most patients were men, age more than 60 years old and the most common etiology was diabetic nephropathy. Average of samples glomerular filtration rate was $9.178 \mathrm{~mL} / \mathrm{min}$ per $1.73 \mathrm{~m} 2$. Urine protein evaluation mostly revealed +3 result. Bivariate analysis found $p=0.118$. The conclusion is no significant relationship between protein urine and glomerular filtration rate of patients with chronic kidney disease in RSUP Dr. M. Djamil Padang dari 2015 sampai 2017.
\end{abstract}

Keywords: chronic kidney disease, urine protein, glomerular filtration rate

Affiliasi penulis: 1. Prodi Kedokteran Fakultas Kedokteran Universitas Andalas Padang (FK Unand), 2. Patologi Klinik FK Unand, 3. Bagian Gizi FK Unand.
Korespondensi: Arief Meiji Surya, Email: ariefmeijisurya@gmail.com Telp: 082382575676 


\section{PENDAHULUAN}

Ginjal merupakan organ yang sangat penting bagi regulasi tekanan darah, fungsi endokrin, transport zat terlarut, air, keseimbangan asam basa dan pembuangan metabolit sisa. Gangguan pada ginjal menyebabkan gangguan fisiologik yang kompleks berkaitan dengan regulasi tersebut. Penyakit Ginjal Kronik (PGK) merupakan salah satu penyakit yang dapat merusak fungsi dari ginjal. Gangguan ginjal yang terjadi berupa kelainan struktur dan penurunan faal ginjal selama $\geq$ tiga bulan dengan manifestasi kelainan patologis komposisi darah,urine atau kelainan dalam tes pencitraan. Nilai penurunan faal ginjal adalah jika Laju Filtrasi Glomerulus (LFG) kurang dari 60 $\mathrm{ml} / \mathrm{menit} / 1,73 \mathrm{~m}^{2}$. Penyakit ginjal kronik biasanya berakhir dengan gagal ginjal dengan terjadinya kerusakan struktur dan fungsi yang ireversibel. ${ }^{1,2}$

Penyakit ginjal kronik menjadi beban kesehatan global dengan biaya ekonomi yang tinggi dalam sistem kesehatan. Penyakit ginjal kronik merupakan salah satu noncommunicable disease mayor menghasilkan outcome kesehatan yang buruk. Menurut Kemenkes tahun 2017 di Indonesia, perawatan penyakit ginjal merupakan ranking kedua pembiayaan terbesar dari BPJS kesehatan setelah penyakit jantung. Total biaya hemodialisis tahun 2012 yang ditanggung oleh PT. Askes dan jaminan asuransi lainnya adalah sebesar 227 milyar rupiah dan merupakan tindakan medis yang menyerap porsi terbesar dari biaya kesehatan. Pembiayaan pelayanan kesehatan oleh BPJS pada tahun 2015 sebanyak 2,68 triliun rupiah dihabiskan untuk penyakit gagal ginjal, baik rawat inap maupun rawat jalan, jumlah tersebut meningkat dari tahun 2014 yang berjumlah sebesar 2,2 triliun Rupiah. ${ }^{3}$

Hasil systematic review dan meta analisis yang dilakukan oleh Hill et al tahun 2016, didapatkan prevalensi penyakit ginjal kronik berdasarkan stagging secara global antara 11 sampai $13 \%$ dengan mayoritas PGK stadium 3. ${ }^{4}$ Insiden dan prevalensi PGK di Indonesia belum diketahui dengan pasti. Menurut Riskesdas tahun 2013, gagal ginjal merupakan penyakit ginjal yang cukup sering dijumpai di Indonesia. Gagal ginjal kronik merupakan salah satu dari 12 penyakit tidak menular yang menjadi masalah utama di Indonesia. Prevalensi gagal ginjal kronik berdasarkan yang pernah didiagnosis oleh dokter pada umur $\geq 15$ tahun di Indonesia adalah 0,2 persen. Jumlah penderita penyakit gagal ginjal kronik di Sumatera Barat juga sama dengan rerata prevalensi PGK di Indonesia yaitu $0,2 \%{ }^{5}$

Mortalitas pasien PGK menurut lama hidup dengan hemodialisis berdasarkan data Kemenkes proporsi tahun 2015 terbanyak pada pasien dengan lama hidup 6-12 bulan yaitu sekitar $33 \%$. Jika dijumlahkan proporsi pasien yang meninggal dengan lama hidup kurang dari 12 bulan adalah sekitar $78 \%{ }^{3}$

Deteksi dini diperlukan untuk meminimalkan biaya, dan memperlambat progresifitas penyakit ginjal kronik, mencegah PGK stadium 5 (End stage) dan menurunkan angka morbiditas dan mortalitasnya. Upaya deteksi dini pada penyakit ginjal kronik dapat dilakukan dengan mengetahui lebih awal adanya proteinuria dan penurunan nilai estimasi laju filtrasi glomerulus. ${ }^{3,6}$

Penelitian National kidney foundation di Amerika serikat merekomendasikan dalam penentuan diagnosis penyakit ginjal kronik dikelompokkan berdasarkan penyebab, laju filtrasi glomerulus, dan kategori albuminuria (proteinuria). Penyebab ditentukan berdasarkan adanya penyakit sistemik dan lokasi patologis ginjal berdasarkan patologi anatomi. ${ }^{2}$

Laju filtrasi glomerulus (LFG) merupakan suatu pemeriksaan fungsi ginjal untuk menilai fungsi ekskresi ginjal, dengan cara menghitung banyaknya filtrat yang dapat dihasilkan oleh glomerulus. Derajat penurunan nilai LFG menandakan beratnya kerusakan ginjal. ${ }^{7}$

Pemeriksaan protein urine hingga kini cukup efektif untuk mengetahui adanya gangguan fungsi ginjal dan dapat dijadikan biomarker yang baik untuk penyakit ginjal kronik. Pemeriksaan protein urine merupakan pemeriksaan rutin yang dilakukan untuk mengetahui fungsi ginjal. Protein dapat masuk ke dalam urine jika terjadi kerusakan pada glomerulus dan tubular. Pemeriksaan protein urine direkomendasikan agar penyakit ginjal dapat terdeteksi dan diobati sebelum menjadi kronik dan semakin parah. Proteinuria atau albumin urine merupakan prediktor potensial dalam menentukan mortalitas. ${ }^{8}$

Penelitian di Taiwan mendeskripsikan bahwa minimal proteinuria atau lebih sering disebut sebagai 
mikroalbuminuria didapatkan pada lebih dari 90\% sampel dengan penyakit ginjal kronik stadium 1 dan stadium 2 , sedangkan pada stadium 3 , stadium 4 dan stadium 5 didapatkan kurang dari $43 \%$. Pemeriksaan mikroalbuminuria biasanya dilakukan untuk mengetahui adanya risiko penyakit kardiovaskular. Berdasarkan klasifikasi overt proteinuria pada stadium 1, stadium 2, stadium 3 didapatkan kurang dari $7 \%$, sedangkan pada stadium 4 mencapai $35 \%$ dan stadium 5 sebanyak $50 \%$ yang terdapat overt proteinuria. Pemeriksaan overt proteinuria biasanya dilakukan dengan metode dipstick (carik celup) dan merupakan pemeriksaan yang penting dalam penyakit ginjal kronik . ${ }^{9}$

Pemeriksaan protein urine dibutuhkan dalam penentuan penyakit ginjal kronik, sedangkan pemeriksaan laju filtrasi glomerulus selain untuk mendiagnosis penyakit ginjal kronik, juga dibutuhkan dalam penentuan stadium dan derajat penurunan fungsi ginjal. Keduanya juga mempengaruhi mortalitas dari penyakit ginjal kronik. ${ }^{6}$ Pemeriksaan protein urine yang diteliti pada studi ini tidak termasuk pemeriksaan mikroalbuminuria tetapi protein urine semikuantitatif karena lebih sederhana dilakukan. Perlu diketahui bagaimana hubungan protein urine dengan laju filtrasi glomerulus pada penderita penyakit ginjal kronik.

Penelitian ini dilakukan dengan tujuan untuk mengetahui karakteristik penderita penyakit ginjal kronik dan hubungan protein urine dengan laju filtrasi glomerulus pada penderita penyakit ginjal kronik dewasa di RSUP Dr. M. Djamil Padang tahun 20152017.

\section{METODE}

Penelitian ini bersifat analitik observasional yang dilakukan di Instalasi Rekam Medis RSUP Dr. M. Djamil Padang Oktober 2017 sampai Maret 2018. Sampel pada penelitian ini adalah penderita penyakit ginjal kronik dewasa yang memiliki data rekam medik hasil pemeriksaan protein urine dan kreatinin plasma dalam satu waktu. Data protein urine diambil dari hasil pemeriksaan dengan cara carik celup. Laju filtrasi glomerulus dihitung dengan menggunakan rumus modification of diet in renal disease. Hasil yang didapatkan diolah secara statistik dengan program komputer menggunakan uji Kruskall-Wallis, bila didapatkan hasil bermakna $(p<0,05)$, maka dilanjutkan dengan uji Post-Hoc Mann Whitney.

\section{HASIL}

\section{Analisis Univariat}

Tabel 1 menunjukkan bahwa dari 40 kasus penyakit ginjal kronik sebagian besar adalah laki-laki dengan jumlah $60 \%$ dari sampel.

Tabel 1. Distribusi jenis kelamin penderita penyakit ginjal kronik

\begin{tabular}{lcc}
\hline Jenis Kelamin & Frekuensi & $\%$ \\
\hline Laki-laki & 24 & 60 \\
Perempuan & 16 & 40 \\
Total & 40 & $100 \%$ \\
\hline
\end{tabular}

Tabel 2 menunjukkan bahwa penyebab terbanyak penyakit ginjal kronik adalah nefropati diabetika sebanyak $45 \%$, dan penyakit ginjal hipertensi sebanyak $30 \%$.

Tabel 2. Distribusi etiologi penyakit ginjal kronik

\begin{tabular}{lcc}
\hline Etiologi & Frekuensi & $\%$ \\
\hline Nefropati diabetika & 18 & 45 \\
Penyakit ginjal hipertensi & 12 & 30 \\
Nefropati obstruktif & 4 & 10 \\
Pielonefritis kronik & 2 & 5 \\
Nefropati asam urat & 2 & 5 \\
Penyakit ginjal polikistik & 1 & 2,5 \\
Glomerulonefritis & 1 & 2,5 \\
\hline Total & 40 & $100 \%$ \\
\hline
\end{tabular}

Tabel 3 menunjukkan bahwa umur penderita penyakit ginjal kronik terbanyak pada umur lebih dari 60 tahun yaitu sebanyak $50 \%$. Rerata umur penderita penyakit ginjal kronik adalah $57,8 \mathrm{SD} \pm 10,350$.

Tabel 3. Umur penderita penyakit ginjal kronik

\begin{tabular}{lccc}
\hline Umur (tahun) & Frekuensi & $\%$ & $\overline{\mathbf{x}}$ \\
\hline $12-24$ & 0 & 0 & \\
$25-44$ & 6 & 15 & 57,8 SD \\
$45-59$ & 14 & 35 & $\pm 10,350$ \\
$>60$ & 20 & 50 & \\
\hline Total & 40 & $100 \%$ & \\
\hline
\end{tabular}


Tabel 4 menunjukkan bahwa hasil pemeriksaan protein urine pada sampel yang terbanyak adalah +3 dengan jumlah $45 \%$ dari sampel.

Tabel 4. Distribusi hasil pemeriksaan protein urine penderita penyakit ginjal kronik

\begin{tabular}{ccc}
\hline Protein Urine & Frekuensi & $\%$ \\
\hline- & 2 & 5 \\
+1 & 9 & 22,5 \\
+2 & 11 & 27,5 \\
+3 & 18 & 45 \\
+4 & 0 & 0 \\
\hline Total & 40 & $100 \%$ \\
\hline
\end{tabular}

Tabel 5 menunjukkan bahwa hasil pemeriksaan laju filtrasi glomerulus pada sampel diperoleh rerata $9,178 \mathrm{~mL} / \mathrm{mnt}$ per $1,73 \mathrm{~m}^{2} \mathrm{SD} \pm 8,1313$.

Tabel 5. Rerata laju filtrasi glomerulus penderita penyakit ginjal kronik

\begin{tabular}{lccc}
\hline Variabel & Rerata \pm SD & Min & Max \\
& $\left(\mathrm{mL} / \mathbf{m n t}\right.$ per $\left.\mathbf{1 , 7 3} \mathbf{~ m}^{2}\right)$ & \\
\hline Laju filtasi glomerulus & 9,178 & 1.7 & 35,5 \\
& $\pm 8,1313$ & & \\
\hline
\end{tabular}

\section{Analisis Bivariat}

Tabel 6 menunjukkan bahwa hubungan protein urine terhadap laju filtrasi glomerulus pada penderita penyakit ginjal kronik dewasa di RSUP Dr.M.Djamil Padang tahun 2015-2017 tidak bermakna secara statistik dengan nilai kemaknaan 0,118.

Tabel 6. Hubungan protein urine dengan laju filtrasi glomerulus pada penderita penyakit ginjal kronik

\begin{tabular}{llccc}
\hline & & $\mathbf{n}$ & $\begin{array}{c}\text { Laju filtrasi glomerulus } \\
\text { Median (Min-Max) }\end{array}$ & $\mathbf{p}$ \\
\hline Protein & - & 2 & $22,4(9,3-35,5)$ & 0,118 \\
Urine & +1 & 9 & $9,3(1,7-33)$ & \\
& +2 & 11 & $5,7(2,5-25,4)$ & \\
& +3 & 18 & $5,5(2,9-16,4)$ & \\
& +4 & 0 & - & \\
\hline
\end{tabular}

\section{PEMBAHASAN}

Frekuensi penderita penyakit ginjal kronik berdasarkan jenis kelamin lebih banyak pada laki-laki dengan jumlah $60 \%$ dibandingkan dengan penderita PGK yang perempuan dengan perbandingan 3:2. Hal ini sesuai dengan data Riskesdas RI tahun 2013 yang menyatakan prevalensi penderita PGK yang laki-laki lebih tinggi dibanding perempuan dengan perbandingan $3: 2^{5}$

Perbedaan jenis kelamin pada penyakit ginjal kronik dipengaruhi oleh variasi risiko seperti hipertensi, albuminuria, indeks masa tubuh, gaya hidup dan hormon seks. Laki-laki memiliki persentase menderita hipertensi yang lebih besar, hiperlipidemia, dislipidemia dan lebih sering merokok dan mengkonsumsi alkohol dibandingkan dengan perempuan. Risiko penyakit ginjal kronik pada laki-laki semakin meningkat jika diikuti proteinuria dan berusia lanjut. $^{10}$

Penderita penyakit ginjal kronik sebagian besar berumur lebih dari 60 tahun dengan umur terendah 38 tahun dan tertinggi umur 74 tahun. Terlihat dari data ini semakin tinggi kelompok umur semakin tinggi frekuensi penderita PGK. Hal ini sesuai dengan penelitian Delima et al. tahun 2014, di empat rumah sakit di Jakarta yang mendapatkan semakin tinggi umur semakin tinggi risiko terkena penyakit ginjal kronik. $^{11}$

Peningkatan usia merupakan risiko terjadinya penyakit kronik seperti diabetes melitus dan hipertensi yang merupakan penyebab utama penyakit ginjal kronik. Insiden hipertensi meningkat seiring pertambahan umur dan memiliki insiden yang lebih tinggi pada orang yang berusia lebih dari 65 tahun, demikian juga dengan diabetes melitus yang memiliki faktor predisposisi jika usia sudah lebih dari 45 tahun, sehingga ikut mempengaruhi kejadian penyakit ginjal kronik yang semakin meningkat seiring pertambahan usia. $^{12}$

Karakteristik penderita berdasarkan etiologi penyakit ginjal kronik yang tertinggi disebabkan oleh nefropati diabetika dan penyakit ginjal hipertensi. Hasil ini sesuai dengan data meta-analisis Hill et al tahun 2016, yang mengatakan terdapat hubungan yang bermakna antara penyakit ginjal kronik dengan penyakit diabetes melitus dan hipertensi. ${ }^{4}$

Nefropati diabetika disebabkan oleh tingginya glukosa yang mengikat residu asam amino untuk menjadi lebih stabil secara terus menerus hingga mengakibatkan terbentuknya Advanced Glycation EndProduct (AGEs). AGEs ini menjadi perantara nodul 
serta fibrosis tubulointersisial dan menyebabkan sklerosis pada ginjal. Hipertensi juga merupakan faktor

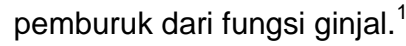

Hipertensi dapat menjadi akibat atau penyebab dari penyakit ginjal kronik, selain kebanyakan dari penderita nefropati diabetika itu sendiri juga menderita hipertensi. Tekanan darah yang tinggi dapat merusak pembuluh kapiler dalam glomerulus yang sering menyebabkan gagal ginjal. Penyakit ginjal kronik juga dapat mengakibatkan hipertensi karena adanya kelebihan volume cairan dan natrium dan karena terganggunya fungsi sistem renin-angiotensinaldosteron. ${ }^{13}$

Hasil pemeriksaan protein urine yang terbanyak adalah +3 . Hasil ini sesuai dengan penelitian Irawati tahun 2004 di RSUP Dr. Kariadi Semarang yang mendapatkan penderita penyakit ginjal kronik paling banyak hasil pemeriksaan semikuantitatif protein urine dengan cara dipstick adalah +3 . $^{14}$

Protein urine adalah salah satu prediktor kuat untuk penyakit ginjal kronik. Proteinuria yang lebih besar mempunyai risiko yang lebih tinggi dalam progresifitas penyakit ginjal kronik. Proteinuria pada penyakit ginjal diakibatkan karena peningkatan permeabilitas dan kerusakan barrier glomerulus, selain itu proteinuria juga disebabkan karena penurunan reabsorpsi tubular sehingga banyak protein yang lolos ke dalam urine. ${ }^{15}$

Hasil pemeriksaan laju filtrasi glomerulus pada sampel diperoleh rerata $9,178 \mathrm{~mL} / \mathrm{mnt}$ per $1,73 \mathrm{~m}^{2}$ dengan Standar Deviasi (SD) $\pm 8,1313$. Hasil ini berarti rerata laju filtrasi glomerulus berada pada stadium akhir ( $<15 \mathrm{~mL} / \mathrm{mnt}$ per $1,73 \mathrm{~m}^{2}$ ). Berbeda dengan penelitian Wen et al. tahun 2008, mendapatkan stadium terbanyak penderita penyakit ginjal kronik adalah stadium 3 dan paling sedikit mendapatkan penderita yang sudah memasuki stadium 5. Hal tersebut disebabkan sampel yang digunakan diambil dengan cara skrining secara nasional dari tahun 1994 sampai 2006 di Taiwan. $^{9}$ Penyebab sebagian besar laju filtrasi glomerulus pada penelitian ini di rentang penyakit ginjal kronik stadium akhir karena sampel yang digunakan di RSUP Dr.M.Djamil adalah pasien rujukan dan karena terdapat unit hemodialisis dan transplantasi ginjal yang merupakan tatalaksana untuk penyakit ginjal kronik stadium akhir.

Hasil uji Kruskal-Wallis didapatkan nilai kemaknaan 0,118. Hal tersebut menunjukkan bahwa hubungan protein urine dengan laju filtrasi glomerulus pada penderita penyakit ginjal kronik di RSUP Dr.M.Djamil Padang tahun 2015-2017 tidak bermakna secara statistik.

Hasil penelitian ini sesuai dengan penelitian Irawati tahun 2004 di RSUP Dr.Kariadi Semarang yang juga tidak mendapatkan hasil yang bermakna antara hubungan protein urine dengan laju filtrasi glomerulus pada penderita penyakit ginjal kronik. Irawati menyimpulkan bahwa protein urine semikuantitatif tidak dapat dijadikan prediktor untuk nilai laju filtrasi glomerulus. ${ }^{14}$ Sesuai dengan penelitian Guh tahun 2010 di Taiwan menyatakan protein urine dapat dijadikan biomarker penyakit ginjal kronik, tetapi pemeriksaan protein urine tidak dilakukan dengan cara semikuantitatif. Metode yang digunakan adalah dengan cara kuantitatif. Menurut Guh metode pemeriksaan protein urine dengan cara dipstick memiliki sensitifitas dan spesifisitas yang lebih rendah dibandingkan dengan pemeriksaan dengan ACR (Albumin to Creatinin Ratio) dan total protein serum dan hanya sensitif terhadap albumin. ${ }^{8}$

Hasil yang berbeda didapatkan oleh Iseki di Jepang tahun 2003 yang menyatakan bahwa protein dalam urine yang diperiksa melalui pemeriksaan carik celup dengan hasil semikuantitatif memiliki hubungan yang kuat dengan terjadinya penyakit ginjal kronik tahap akhir. ${ }^{16}$ Penelitian ini berbeda karena tidak secara langsung melihat hubungannya dengan laju filtrasi glomerulus, tetapi melihat hubungan proteinuria dengan PGK yang sudah memasuki tahap akhir sehingga tidak mendukung jika protein urine semikuantitatif memiliki hubungan yang bermakna dengan laju filtrasi glomerulus. Pemeriksaan protein urine dengan cara semikuantitatif lebih cocok digunakan sebagai skrining awal. ${ }^{15}$

Kelemahan pemeriksaan protein urine secara semikuantitatif dengan cara dipstick adalah paling utama hanya mendeteksi albumin dan tidak mendeteksi immunoglobulin atau protein rantai ringan. Pemeriksaan ini juga tidak dapat mendeteksi albumin 
dalam konsentrasi yang lebih kecil (mikroalbuminuria) Hasil pemeriksaan protein urine dengan cara dipstick perlu diikuti pemeriksaan protein urine secara kuantitatif, karena prognosis dan tatalaksana sering tergantung dari derajat proteinuria. Pemeriksaan protein urine secara kuantitatif dapat diperiksa dengan metode ACR dan PCR. ${ }^{15}$

Keterbatasan dalam penelitian ini adalah sampel yang diambil dari rumah sakit rujukan pusat sehingga sebagian besar sampel sudah memasuki penyakit ginjal kronik stadium akhir dan tidak ditemukan kasus PGK stadium awal. Pemeriksaan protein urine dengan cara semikuantitatif yang merupakan variabel dalam penelitian ini lebih direkomendasikan sebagai deteksi awal di fasilitas kesehatan layanan tingkat pertama.

\section{SIMPULAN}

Hubungan protein urine dengan laju filtrasi glomerulus pada penderita penyakit ginjal kronik dewasa di RSUP Dr. M. Djamil Padang tahun 20152017 tidak bermakna secara statistik.

\section{DAFTAR PUSTAKA}

1. Suwitra K. Penyakit ginjal kronik. Dalam: Sudoyo AW, Setyohadi B, Alwi I, Simadibrata M, Setiadi S, editor (penyunting). Buku ajar ilmu penyakit dalam jilid I Edisi ke-4. Jakarta: Departemen IImu Penyakit Dalam FKUI; 2007: 581-4.

2. Vassalotti JA, Centor R, Turner BJ, Raquel C. Greer RC, Choi M, Sequist TD. Practical approach to detection and management of chronic kidney disease for the primary care clinician. The American Journal of Medicine. 2016;129:153-62.

3. Kementrian Kesehatan RI (Kemenkes RI). Situasi penyakit ginjal kronis 2016. Jakarta: Pusat Data dan Informasi Kemenkes RI; 2017.

4. Hill NR, Fatoba ST, Oke JL, Hirst JA, O'Callaghan $\mathrm{CA}$, Lasserson DS, et al. Global prevalence of chronic kidney disease - a systematic review and meta-analysis. PLoS ONE. 2016;11(7): e0158765.

5. Departemen Kesehatan RI. Penyakit Ginjal Riset. kesehatan dasar (Riskesdas) 2013. Badan Penelitian dan Pengembangan Kesehatan Kementrian RI (diunduh 2 Agustus 2017). Tersedia dari: https://www.depkes.go.id/hasil-riskesdas-2013

6. James MT, Hemmelgarn BR, Tonelli M. Early recognition and prevention of chronic kidney disease. Lancet. 2010;375:1296-309.

7. World Health Organization (WHO). Pedoman teknik dasar untuk laboratorium kesehatan. Edisi ke-2. Chairlan, Lestari E, penterjemah. Jakarta: EGC; 2011.

8. Guh JY. Proteinuria versus albuminuria in chronic kidney disease. Asian Pacific Society of Nephrology. 2010;15:53-6.

9. Wen CP, Cheng TYD, Tsai MK, Chang Yc, Chan HT, Tsai SP, et al. All-cause mortality attributable to chronic kidney disease a prospective cohort study based on 462293 adult in Taiwan. Lancet. 2008;371:2173-82.

10. Chang PY, Chien LN, Lin YF, Wu MS, Chiu WT, Chiou HY. Risk factors og gender for renal progression in patient with early chronic kidney disease. Medicine (Baltimore). 2016 Jul 29; 95 (30):e4203.

11. Delima, Tjitra E, Tana L, Halim FS, Ghani L, Siswoyo $\mathrm{H}$, et al. Risk factors for chronic kidney disease : a case control study in four hospitals in Jakarta in 2014. Buletin Penelitian Kesehatan. 2017 Mar; 45(1):17 -26.

12. Ikatan Dokter Indonesia (IDI). Panduan praktik klinis bagi dokter di fasilitas pelayanan kesehatan primer. Edisi ke-1. Jakarta: Kementrian Kesehatan $\mathrm{RI} ; 2013$.

13. Bayhakki. Klien gagal ginjal kronik. Jakarta: EGC; 2006.

14. Irawati M. Proteinuria semikwantitatif sebagai prediktor penurunan laju filtrasi glomerulus yang dinilai dengan perubahan cystatin $\mathrm{C}$ dalam 1 tahun pada penderita penyakit ginjal kronik (tesis). Semarang: Universitas Diponegoro; 2004.

15. National Institute of Health. Association of estimated glomerular filtration rate and albuminuria with mortality and end-stage renal disease: a collaborative meta-analysis of kidney disease cohorts. Kidney Int. 2011 June;79(12):1331-40.

16. Iseki K, Ikemiya $Y$, Iseki $C$, Takishita S. Proteinuria and the risk of developing end-stage renal disease. Kidney Int. 2003 Apr;63(4):1468-74. 